\title{
Effects of innovative teaching methods on students' academic performance: An empirical study on financial accounting
}

\section{Efectos de los métodos de enseñanza innovadores en el rendimiento académico de los estudiantes: un estudio empírico sobre la contabilidad financiera}

$\begin{array}{llll}\text { Francisca Tejedo- } & \text { Carolina Pontones } & \text { Yolanda Ramírez } & \text { Ángel Tejada Ponce } \\ \text { Romero } & \text { Rosa } & \text { Corcoles } & \text { Angel.Tejada@uclm. } \\ \text { Francisca.Tejedo@ } & \text { Carolina.Pontones@ } & \text { Yolanda.Ramirez@ } & \text { es } \\ \text { uclm.es } & \text { uclm.es } & \text { uclm.es } & \end{array}$

Departamento de Administración de Empresas.

Universidad de Castilla-La Mancha, Albacete,

Fecha de recepción: 17-03-2014

Fecha de revisión: 24-11-2014

\section{Keywords:}

\section{España}

Financial Accounting; Academic

Performance; Learning Evaluation; Didactic

Methodology.

The implementation in Spain of the La implantación en España del Espacio European Higher Education Area has Europeo de Educación Superior ha supuesto involved a substantial change in traditional practices of university education, introducing important modifications both to the teaching methodology and the evaluation criteria.

The objective of this work is to determine whether there is a relationship between the methodology and the evaluation scheme used and the results obtained by the students, differentiating academic years in which different methodologies were applied within the framework of the ECTS philosophy. To
Fecha de aceptación: 25-05-2015 Fecha de publicación: 15-06-2015

\section{Contabilidad Financiera; Rendimiento Académico; Evaluación De Aprendizaje; Metodología Didáctica.}

un cambio sustancial en las prácticas tradicionales de la educación universitaria, introduciendo importantes modificaciones tanto en la metodología de la enseñanza como en los criterios de evaluación.

El objetivo de este trabajo es determinar si existe una relación entre la metodología y el sistema de evaluación utilizado y los resultados obtenidos por los alumnos, diferenciando años académicos en los que se aplican diferentes metodologías en el marco 
this aim this work focuses on the results achieved for the Financial Accounting subject, located in the first course of the Management and Business Administration degree. Firstly, a depiction of its electronic guide is undertaken, showing the teaching methodology followed for the subject. Afterwards, the results of the research are displayed, analyzing the relationships between the applied methodology and the marks achieved by the use of contingency tables and Pearson's chi-square tests. de la filosofía ECTS. Para ello, este trabajo se centra en los resultados obtenidos en la asignatura de Contabilidad Financiera, que se encuentra en el primer curso del Grado en Administración y Dirección de Empresas. En primer lugar, se realiza una descripción de la guía electrónica, mostrando la metodología de enseñanza seguida por la asignatura. A continuación, se muestran los resultados de la investigación, el análisis de las relaciones entre la metodología aplicada y los resultados logrados mediante el uso de tablas de contingencia y la prueba chi-cuadrado de Pearson.

\section{Introducción}

Higher education is one of the main instruments of companies to encourage the development of their economies, since public expenditure destined to support the cost of higher education is really an investment of the whole society in the human capital formation.

Therefore, the students comprise the main social capital of a country, with the nation's development depending on the education of its young generations (Pasek et al., 2006). This justifies the change of the university education model promoted by different European countries, Spain included, through the Bologna Process, fostering students' acquisition of the skills and abilities required to enter the job market (Martinello and Cook, 2000).

The achievement of the Bologna goals and the establishment of a European Higher Education Area of quality require the modification of the educational system, developing a professional profile, roles and activities different from the traditional in the students and the professors (Monereo and Pozo, 2003). Teachers should assume new competencies that affect concepts and attitudes on education and learning within the framework of training projects (Zabalza, 2003; Camacho, 2012). Also, the student must assume its protagonist role in the educational process, developing an autonomous learning 
that should be meaningful and cooperative (Mateos and Marín, 2009).

Undoubtedly, this process requires a significant change of mentality in the dominant culture of students and university teaching staff, and a cooperative work of both oriented towards the learning results. In this sense, teachers should select appropriate methodologies for achieving the proposed objectives, using as a reference the academic profile and characteristics of professional skills training (Cañibano, 2008), in addition to structural and organizational conditions in which these activities will be carried out (group size, space, educational organization, etc.).

In this context, a large literature focuses on analyzing the factors determining the students' academic success in different areas of knowledge, with the aim of promoting measures or changes in educational policy that reduce the high university drop-out rate and provide a well-trained active population (Martí, 2012).

However, despite the efforts made, the European Union member states present a high school drop-out rate (European Commission, 2011). In particular, in Spain, the academic drop-out and/or failure rate of university students reached $35 \%$ on average, during the 2004-2009 periods, according to data provided by the Ministry of Education and the National Statistics Institute.

University faculties and administrators are making a great effort to ensure that students receive quality education with an increasingly reduced budget allowance (Martí, 2012). Considering this situation, knowing the main pedagogical methods that determine the students' academic performance in higher education is primordial.

Admitting that teaching-learning processes and evaluation systems are closely related (Col et al., 2007; Fernández-Barberis et al., 2006; López-Pastor, 2009), the paper aims to determine whether the new teaching methodologies and criteria for evaluation used in recent years have impacted positively on the improvement of the students' academic performance. In order to achieve this, this paper compares the qualifications obtained by students during the academic years 2008-2009, 2009-2010 and 2010-2011 (where different proactive learning and evaluation tools were applied) within the subject Financial Accounting. This subject is located in the first course of the Management and Business Administration Degree of the Faculty of Economics and Business Administration of Albacete (University of Castilla-La Mancha, Spain).

This paper is structured as follows. In section 2 the theoretical framework is introduced, as well as a literature review. Section 3 describes the learning and evaluation tools envisaged by the teaching guide of the subject Financial Accounting during the three academic years. In section 4 , the results from our empirical study are discussed. Lastly, some concluding comments are provided. 


\section{Theoretical background and literature review}

One of the key aspects in the elaboration of teaching guides is the methodology and criteria of evaluation.

It is essential to highlight, despite being obvious, the acceptance of the system of continuous evaluation as a basic part of the new European credit system. This system is considered the most useful and consistent approach to evaluate the objectives of the subjects, as reflected in the publication of Common European Framework of Reference for Languages: Learning, Teaching, Assessment (Council of Europe, 2001). This European credit system has become an indispensable reference point for European convergence in questions related to the education.

The continuous evaluation is the result of the improvement of different evaluation procedures, which arises from the consideration of the educational process as an evolution that occurs over the entire training period (Imbernón, 1998 and Colen et al., 2006), by applying methods that positively affect the student's learning. However, "pure" systems of continuous evaluation are not usually used, but these methods are added to typical methods or procedures of other formative evaluation systems, summative evaluation or self-evaluation (Cabrera, 2003; Delgado and Olivier, 2009; López, 2001). These modifications are intended to maximize the chances of student feedback so that, being aware of their strengths and weaknesses from the first moment, they can take a leading role in the development of their own learning throughout the educational period (Delgado and Olivier, 2006; Fernández-Barberis et al., 2006).

Consequently, to be successful this methodology requires a change in the way of work, both for teachers and students, and therefore a change in the methods applicable to the subject, where the student becomes an active part of this process and the teacher is no longer the protagonist of education and becomes the person who structures the learning process, the supervisor and tutor of works (Barnet and Di Napoli, 2008). The figure of the teacher becomes "a companion in the process of learning, who helps students to achieve certain competencies" (González and Wagenaar, 2003, 74). The teacher should lead, stimulate and promote the learning process, but also to monitor and assess it (Delgado and Olivier, 2009; Cuadrado and Fernández, 2008). Consequently, it is logical to equip the evaluation with one double mission, because it must have both pedagogical and accreditation purposes (Plaza et al., 2010).

As the objective of higher education is to foster high quality learning (Davidson, 2002), educators need to understand the factors that influence students' engagement in the learning process and that subsequently impact on academic performance (Biggs, 1999).

In this context, an important part of the 
education literature focuses on examining whether active learning methods surpass or not the traditional method (where the student plays a passive role in its own learning) (Michel et al., 2009). In the case of Spanish universities, the study of Pérez and Vila (2012) evidences that, in general, proactive methods such as problem-based learning, practical knowledge and practices in companies are especially influential in the development of different capacities and competitions of future graduates, whereas more traditional methods such as attendance to class, written assignments and the teacher as the main source of information, present, on the contrary, little or no influence.

Also, in the field of university education in Accounting, several studies (Porter and Carr, 1999; Demski and Zimmerman, 2000; Albrecht and Sack, 2000; Archer and Hutchings, 2000; Burnett, 2003) indicate the convenience of introducing appropriate pedagogical innovations and changes in evaluation systems that allow students to develop professional competencies and abilities of this area of knowledge (Gandía and Montagud, 2011). On the other hand, in the field of Financial Accounting, some relevant studies exist on how students' performance can be affected depending on the use of certain methodological techniques. Besides, other research question whether the new evaluation methodologies promoted at the European Higher Education Area (EHEA) are suitable to assess the students' performance (Pascual et al., 2011).
Some of these studies show that student's critical analysis must be reflected clearly in the final tests; others studies focus on the effect that new technologies (e-learning) have in the rates of student's success (Perera and Richardson, 2010); some others incorporate the case methodology to promote a deep learning, incorporating affective and institutional factors of the students (Healy and McCutcheon, 2010); other empirical results confirm that students' academic performance is better in those groups that receive innovative teaching methods, opposite to those groups that receive traditional methods (Gandía and Montagud, 2011).

Finally, at the national level (Spain) it is worth highlighting the works of Mateos and Marin (2009), Carrasco et al. (2010), Pons and Mauleón (2010), Barnabé et al. (2011) and López et al. (2011), which demonstrates the effectiveness of using active methodologies in the subject Financial Accounting. Thus, Carrasco et al. (2010) demonstrate the effectiveness of active participation methodologies (project-based learning and activity-based learning) to improve the students' performance in the subject Financial Accounting. Similarly, the results of the work of Mateos and Marín (2009) show a remarkable correlation between the academic results obtained by students in the subjects of Accounting and their participation in active methodologies of problem-based learning through the intensive use of information and communication technologies (ICT). In the same line, López et al. (2011) show that 
the undertaking activities on the web by Financial Accounting students has a positive impact on their results. On the other hand, the work of Bernabé et al. (2010) evidences that the introduction of new evaluation instruments results in an improvement of the marks obtained by students in the subject Financial Accounting.

In conclusion, in recent years the theoretical contributions and empirical studies have increased in order to determine the causes of students' academic performance in higher education. However, it is also necessary to develop empirical studies that demonstrate which of the main proactive educational and evaluation methods have a greater impact on the students' academic performance. In this line, our paper questions whether the new evaluation methods to assess the students' academic performance are appropriate.

\section{Description of the teaching methodology for the subject "financial accounting" over the academic years considered}

The subject Financial Accounting is currently located at the first course in the curriculum of Bachelor's degree in Business Administration, with a load of 9 credits, equivalent to 225 hours of work by the student, both face-toface and distance.

The teaching guide of this subject has evolved, especially as far as evaluation activities are concerned, throughout the three considered periods: 2008-2009, 2009-10 and 2010-2011. Despite the fact that during this time the Guide has maintained a structure and common content, which is described briefly in the following lines, also methodological differences have been introduced conferring a different character to each one of the periods. These differences will be the main object of our attention.

Firstly, the teaching guides start with general information about teaching staff, hours of tutoring, prerequisites for the course, the subject relationship with other subjects and impact on future professional activity of graduates. With respect to the prerequisites, they are not considered necessary and essential for the student to complete this course, although they must show predisposition to daily work to properly address the continuous assessment methodology. Regarding the relationship of this subject with others of the degree and its impact in the workplace, this course represents an important piece in the learning and understanding of other multidisciplinary subjects of the degree in Business Administration and, at the same time, aims to provide the student with one of the basic instruments to carry out business management, such as the ability to prepare and understand financial and economic information, being this key for decisionmaking.

Subsequently, guides detailed the objectives 
to be achieved and the competencies to be developed by the student relating to curriculum. Another common section is the syllabus of the subject, consisting of fifteen themes that encompass from the foundations of the Accounting Science to the accounting process concerning specific assets and complex operations.

However, the main variation across the three considered academic years is the one relating to the evaluation and teaching methodology system. The ways of assessment is a fundamental issue that affects the entire process of teaching and learning (PerezParedes and Rubio, 2005). It must be in line with the objectives and global competences already referred (Camilloni, 1998; Delgado et al., 2005; Diaz, 2002) and it must be transmitted clearly to the students, so they understand the importance of each assessment activity with a view to the obtaining of the final grade for the course. The methodology used is explained below, making a distinction between activities where the teacher takes a leading part and those in which the student has to play an active role, either face to face or distance.

First, we will describe the evaluating activities included in the guides where the teacher takes a leading part, being all of them common throughout the three considered academic years:

- Classroom teaching (theory): The development of this training activity is carried out using an expositive methodology or lecture. In this sense, theoretical and practical face to face classes are provided, aimed at clarifying the main concepts and bases of the syllabus previously specified, so the student can reach, along with the material means placed at its disposal, to the achievement of the objectives and competences outlined in the teaching guide. It is considered as a non-mandatory training activity and since it is not possible to replicate the same scenario in the extraordinary exam, it is considered a non-recoverable activity.

- Classroom teaching (practice): This training activity is developed through exercises and problems resolution. It consists of practical classes of face to face nature aimed at the clarification of the main concepts through the realization of practical cases, in order that these become a part of the student's working material and serve as a basis for the configuration of their portfolio.

With regard to the activities that require an active participation of the student, those which are common to the three academic years considered are described next:

-Seminars: these consist of regular meetings with students, face-to-face nature, in which teachers resolve additional exercises which, preferably, would have been suggested by the students, in order to deepen and clarify concepts that have not been addressed in more detail in the class schedule. It is a non-mandatory activity and non-recoverable. 
- Attention in tutorials: individually or in a group, the student may attend hours of tutorials that have been established by their teachers, in order to seek guidance and resolve their doubts with regard to the understanding and overcoming of the subject. It is a non-mandatory activity and non-recoverable.

- Partial tests: consisting of written exams that combine multiple-choice questions (theoretical and practical) and practical cases. They are timed, carried out under control and provided with preset marking criteria, well-known both by teachers and students. Multiple-choice tests are considered useful to assess the acquisition of knowledge, whereas the practical cases pursue evaluating the capacity of expression, organization of ideas, the level of application of knowledge, the capacity of analysis and the creativity of the student. Two partial tests are performed throughout the course, accumulating matter in each one of them. Both present an obligatory character and are recoverable, although in a different percentage according to the academic year considered.

- Final exam, which adopts a similar structure to the partial test referred, that is, combining practical and theoretical questions, but including all the topics studied in the course. It is considered useful for the learning and evaluation of the skills acquired throughout the course such as the accounting concepts and procedures learnt, the ability to apply knowledge to practice and the reasoning skills. Its character is mandatory and recoverable but, as in the previous case, in a different percentage according to the considered academic year.

- Improvement test: designed for those students who achieve certain performance (a mark of four out of ten on the weighted average of the partial exams), this oral test gives the opportunity to students to upgrade their final mark. Held at a public meeting, in it the student must answer or resolve some questions concerning both theoretical and practical accounting issues. In addition, it permits to assess transversal competences required in a public exhibition, such as the ways of expression, the capacity for synthesis and the quality of exposure. Its character is non-mandatory and non-recoverable. - Autonomous work by the student: it concerns the time that the student must invest in the preparation of tests and exams. It is the work conducted outside the classroom which is necessary to overcome the subject of "Financial Accounting". In the opinion of Rico and Rico (2004), this autonomous work represents a form of learning in which the student is responsible for the organization of its own work, the acquisition of knowledge and its assimilation at their own rhythm. This activity has a non-obligatory character and is not recoverable. As regards the evaluating activities that require the 
student to play an active role, it must be noted that they have been applied only according to the needs detected over the three periods analyzed, constituting the main methodological innovation that, in the next pages, will be put into relation with the findings gathered from the statistical analysis of the student's results (final marks). These are the following two:

- An individual case, whereby the student must overcome a set of practical cases referred to the whole syllabus of the subject. Designed for individual students, it grows from simple operations to the accounting process of complex transactions over different financial years. These cases were delivered to the students at the beginning of the course its resolution was monitored throughout the period. For its accomplishment, the student has at his/her disposal the teachers' advice within their tutoring schedule. On the other hand, it presents a non-mandatory character but is a non-recoverable activity. It must be highlighted the fact that the inclusion of this cases within the evaluation methodology took place exclusively in the first of the periods considered, that is 2008-2009, and was suppressed after it. This decision was based on several reasons ranging from the increased workload for the student to possibility of copying among students or the excessive complexity of the evaluation system.

- Oral tests of progress: consisting of three periodic tests whereby the student, previously to its holding, is required to prepare and submit a number of questions related to the topics covered in the course. The day where the tests are held, a competition is organized and, by drawing, students ask to each other in an oral way. These tests are performed in class time and evaluate knowledge, expression and synthesis capabilities. They are voluntary nature and non-recoverable. This activity was applied during the 20082009 in groups of one hundred students, which obliged to form groups of four students for competition. The fact that students' failures affected their group mates gave rise to complaints. On the other hand, the number of students hampered an agile development of the tests. In order to solve these drawbacks, during the academic year 2009-2010 these tests were organized in groups of 25 students, which forced to use more space and teachers, but that allowed a better follow-up of student's progress and permitted the students to participate individually.

During the last period considered, 2010-2011, these oral tests of progress were abolished, mainly due to the lack of resources for its proper development, because they involved a great extra job of supervision for teachers and, on the other hand, due to the poor quality of the questions prepared by students themselves, forcing teachers to continuously 


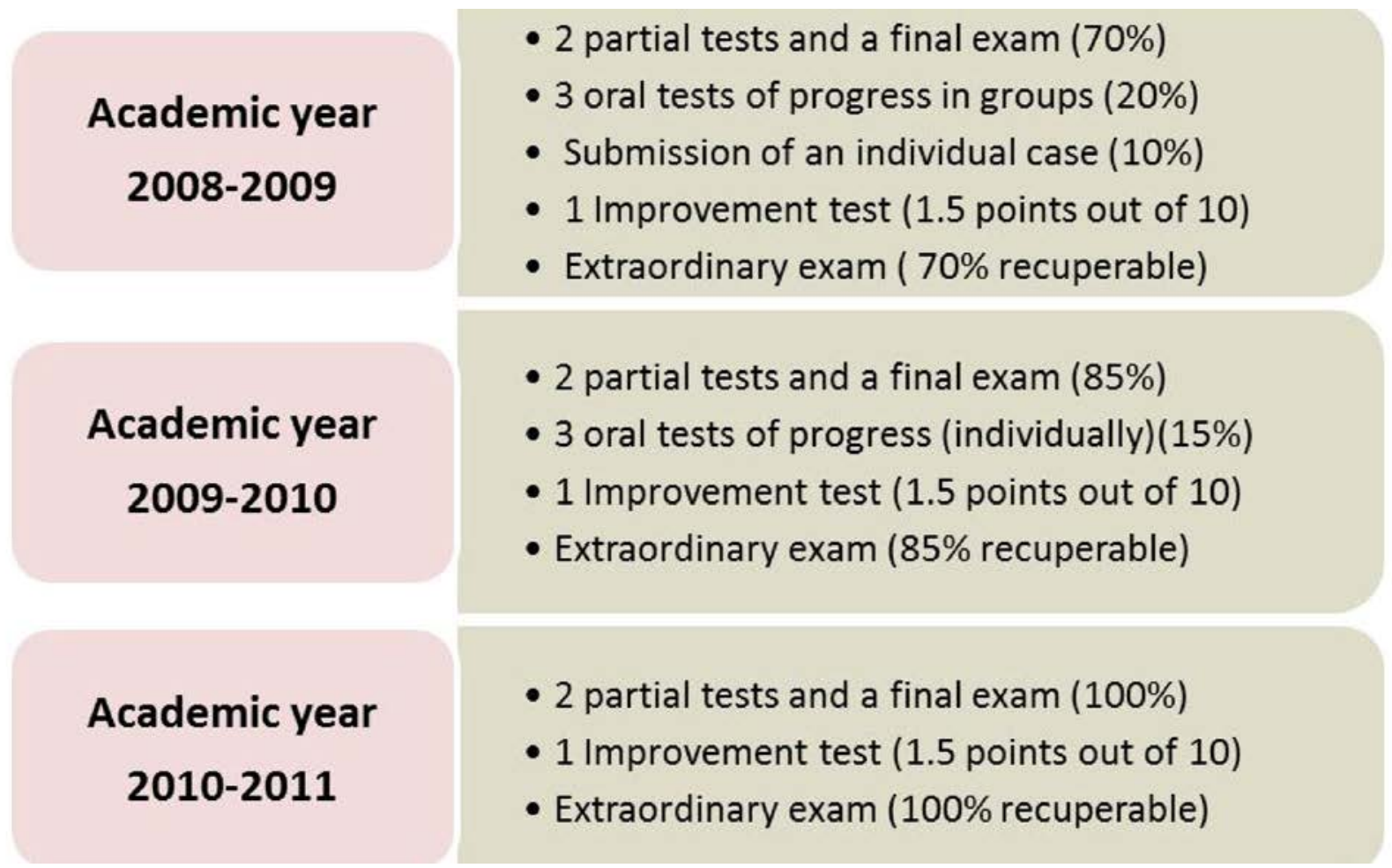

Figure 1: Grading scheme.

demand their reformulation.

Finally, and leaving aside the section of recommended bibliography included in the teaching guides, it remains to explain the grading scheme applied to the subject in each of the academic years studied, which is underpinned by the assessing activities described above. The following figure 1 provides an overview of this scheme.

From the figure above, it can be noticed that the evaluation methodology and, consequently, the grading scheme have evolved towards a simpler system over the three academic years analyzed. In particular, during the first period, 2008-2009, two partial tests and a final exam where accompanied by three oral tests of progress and by the submission of an individual case.

Subsequently, in the academic year 20092010 the individual case was withdrawn and the grade associated to the oral tests of progress was reduced, for the benefit of partial tests and final exam. This decision is due to the fact that, given the large number of students, each of them had the opportunity to participate three times in each test at a maximum, being sometimes the case that students' answers didn't allow the teacher to determine the degree of knowledge and the possession of other skills. This situation led to considering that linking a $20 \%$ of the overall mark to these oral tests might be excessive. In the following academic year, 2010-2011, oral tests of progress were definitively suppressed, which meant that he written tests and exam accounted for the total score. However, in all periods an oral-nature improvement test persisted, although it was only accessible for students who had obtained a certain performance in the written tests. On the 
other hand, the possibility of recovering the marks at the extraordinary exam raised every academic year, insofar the written tests/exam gained weight in the overall grade.

\section{Empirical study}

\subsection{Description of the population analyzed}

The starting point for the empirical part of this research are the final marks obtained by students registered at the first course of the degree on Business Administration at the Faculty of Economics and business of the University of Castilla - La Mancha, Albacete (Spain) over the three academic years selected. Table 1 presents the population covered by the study.

\subsection{Analysis of the results}

As it has been pointed out, the main objective of our research is to identify the relationships existing between the results obtained by the students and the methodology of evaluation applied. To this end, a descriptive analysis will show the evolution of final marks of students taking exam, measured through a numerical number referred to a scale of ten points, following the Spanish marking system. Subsequently, an analysis using contingency tables is carried out leading to verify the existence of relationships between the variables studied (results obtained by the students, measured through literal marks, versus academic years' methodology).

\begin{tabular}{ll}
\hline Academic year & Students enrolled \\
$2008-09$ & 211 \\
$2009-10$ & 209 \\
$2010-11$ & 308 \\
TOTAL & $\mathbf{7 2 8}$ \\
\hline & \\
Table 1 Students enrolled in Financial Accounting
\end{tabular}

With that aim, Pearson's Chi-square test is applied to the contingency tables referred to, enabling to contrast the null hypothesis of independence between the aforementioned variables.

As far as the selection of variables is concerned, it is worth highlighting that learning outcomes are usually measured through academic achievements, the improvement of learning habits or the acquisition of competences and skills (Lei, 2010). In this research, the students' learning outcomes will be measured through academic achievement, in particular through the final marks obtained (Broad et al., 2000; Dowling et al., 2003; Drennan 
and Rohde, 2002; Farley and Ramsey, 1988; Freeman and Capper, 1999).

\subsection{Descriptive analysis}

In order to understand the behavior of the results obtained by the students over the

possible points, whereas the highest mark three academic years considered, a descriptive achieved in 2008-2009 was only 7.5. On the analysis has been accomplished resulting in opposite, the lowest mark in academic years 2009-2010 and 2010-2011 was 0 points, akin the statistics gathered in table 2. It can be to the 0.1 points corresponding to 2008-2009. appreciated that academic year 2010-2011 Finally, it must be noted that the coefficient

\begin{tabular}{lllllll}
\hline Academic year & N & Minimum & Maximum & Mean & Std. & Coef. \\
& & & & & Deviat. & Variation \% \\
\hline $2008-2009$ & 189 & 0.10 & 7.50 & 2.94 & 2.11 & $71.80 \%$ \\
$2009-2010$ & 198 & 0.00 & 10.00 & 2.98 & 2.49 & $83.39 \%$ \\
$2010-2011$ & 288 & 0.00 & 10.00 & 3.25 & 2.58 & $79.37 \%$ \\
\hline
\end{tabular}

Table 2: Descriptive Statistics (students taking exam).

presents an average final mark (3.25) which of variation, indicative of data dispersion, exceeds the correspondent to the periods is higher in the second period, 2009-2010, 2009-2010 (2.98) and 2008-2009 (2.94). As to reaching an $83.39 \%$, followed by a $79.37 \%$ in the number of students taking exam, it can be $2010-2011$ and by a 71.80 in 2008-2009.

observed how it has increased from 189 in the By way of synthesis, Figure 2 shows the academic year 2008-2009 to 198 and 288 in trend followed by the average results over the academic years 2009-2010 and 2010-2011, the three academic years analyzed. It can be respectively. On the other hand, the highest appreciated a slight rise in the average marks score was obtained by students in 2009-2010 as periods pass.

and 2010-2011, reaching the maximum of ten

\section{Average mark}

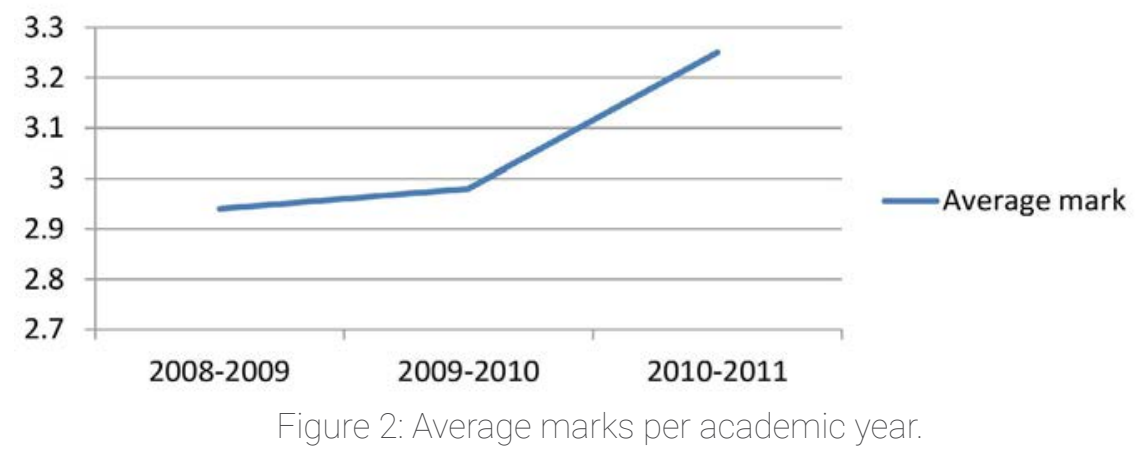




\subsection{Contingency tables and Pearson's Chi-squared Test}

In undertaking this analysis the whole population was used as sample, in particular 211 students enrolled in 2008-2009, 209 students enrolled in 2009-2010 and 308 students enrolled in 2010-2011.

Table 3 contains a comparison of the results obtained by students for each analyzed academic courses. The following remarks are applicable:

- A $10.4 \%$ of students did not take exam in 2008-2009, compared to a $5.3 \%$ in 20092010 and to $6.5 \%$ per cent in $2010-2011$. These results show an overall decrease in that rate throughout the three academic years, which could indicate a greater motivation by students to overcome the subject.

- The percentage of students failing the subject decreases from a $69.7 \%$ (2008-
$2009)$ to a $68.4 \%(2009-2010)$ and to a $63.6 \%(2010-2011)$.

- An upward trend can be detected in the percentage of students obtaining "pass", from a $15.2 \%$ in the first period considered until a $19.6 \%$ and a $20.5 \%$ in the two last academic years.

- Similarly, the percentage of students evaluated as "very good" increases every academic year, being $4.7 \%$ in 2008-2009 and reaching a 7.8\% in 2010-2011.

- "Excellent" marks were obtained exclusively in academic course 2009-2010, reaching a $1.9 \%$.

- As to the highest evaluation, "outstanding", a positive evolution has occurred, progressing from $0 \%$ in 20082009 to $0.5 \%$ in the following year and to $1.6 \%$ in $2010-2011$.

\begin{tabular}{llll}
\hline & Academic year & Academic year & Academic year \\
& $\mathbf{2 0 0 8 - 2 0 0 9}$ & $\mathbf{2 0 0 9 - 2 0 1 0}$ & $\mathbf{2 0 1 0 - 2 0 1 1}$ \\
\hline Exam not taken & $22(10.4 \%)$ & $11(5.3 \%)$ & $20(6.5 \%)$ \\
Fail & $147(69.7 \%)$ & $143(68.4 \%)$ & $196(63.6 \%)$ \\
Pass & $32(15.2 \%)$ & $41(19.6 \%)$ & $63(20.5 \%)$ \\
Very good & $10(4.7 \%)$ & $9(4.3 \%)$ & $24(7.8 \%)$ \\
Outstanding & $0(0.0 \%)$ & $4(1.9 \%)$ & $0(0.0 \%)$ \\
TOTAL & $0(0.0 \%)$ & $1(0.5 \%)$ & $5(1.6 \%)$ \\
\hline
\end{tabular}

Table 3. Contingency table: Final marks * Academic year (Marks obtained in ordinary call). 


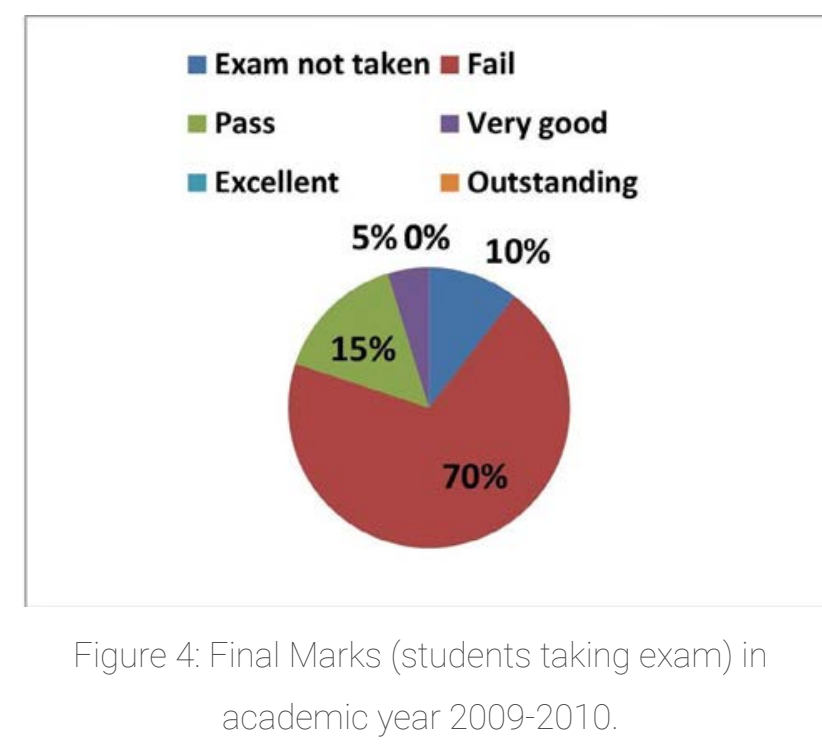

Consequently, most of the measures of students' achievement show an improvement throughout the period considered. This fact points to simpler and less participative evaluation methodologies being related to higher student performance and motivation.

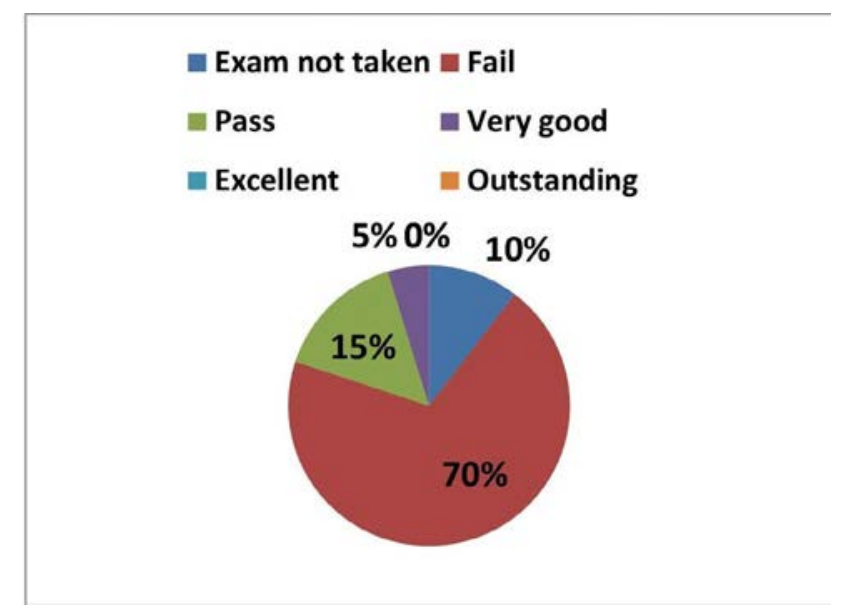

Figure 5: Final Marks (students taking exam) in academic year 2010-2011.

It can be observed (see Figures 3, 4 and 5) that there is a relation between the results obtained by students for each of the academic years. In this regard, the results presented in Table 4 show that Chi-square test $(\mathrm{p}$-value $=0.006)$ is significant, which means that differences between the methodologies used in each of the academic years were statistically significant with a $95 \%$ significance level. That is, there is a significant association between the marks obtained and the methodology used.

\begin{tabular}{llll}
\hline & Value & df & Asymp. Sig. (bilateral) \\
\hline Pearson's chi-square & $24.724^{\mathrm{a}}$ & 10 & 0.006 \\
Likelihood ratio & 25.873 & 10 & 0.004 \\
Linear-by-linear association & 9.512 & 1 & 0.002 \\
Number of valid cases & 728 & & \\
\hline \multicolumn{1}{c}{ 6 cells (33.3\%) have expected frequencies less 5. The minimum expected cell } \\
frequency is 1.15.
\end{tabular}

\section{Table 4. Chi-square test.}

Finally, it must be noted that the results obtained in this study are in line with those obtained by Pascual et al. (2011), since everything seems to indicate that more active methodologies, and therefore more complex evaluation schemes, have a negative impact on academic results. However, the results of studies conducted by Mateos and Marín (2009), Carrasco et al. (2010), Pons and Mauleón (2010), Bernabé et al. (2011), López et al. (2011) and Zafra et al. (2011) demonstrate the effectiveness of using active methodologies in subjects of Accounting. This controversy indicates the need to undertake further empirical research in the field of study. 


\section{Conclusions}

The implementation in Spain of the European Higher Education Area (EHEA) has involved a substantial change in traditional practices of university education, introducing important modifications both to the teaching methodology and the evaluation criteria.

Teachers and students should select appropriate working methods to achieve training objectives and competencies in each degree, using as a reference the academic profile and characteristics of professional skills training.

Consequently, for this teaching methodology to be successful it is required a significant change in the form of work, both for teachers and students. Therefore it requires a change in the methods applied in the course, where the student becomes an active part of this process and the teacher is no longer the protagonist of education and becoming the person who structures the learning process, the supervisor and director of works.

It is necessary to introduce appropriate pedagogical innovations and changes in assessment systems that allow students to develop professional skills and abilities of each knowledge area.

In relation to the results achieved in our study, we obtained a slight rise in the average marks in each one of the years analyzed. Furthermore, the results of contingency tables and Chi-square test show that differences between the methodologies used in each of the academic years were statistically significant with a $95 \%$ significance level.

The results of this empirical study are fully consistent with the results obtained in the work of Pascual et al. (2011), demonstrating the ineffectiveness of using certain active methodologies in Financial Accounting subject, which leads us to question the assessment method established in this subject in order to promote better alternatives to implement other types of evaluation under European Higher Education Area (EHEA).

\section{References}

\section{References}

Albrecht, E. S. \& Sack, R. J. (2000). Archer, L., \& Hutchings, M. (2000). 'Bettering Accounting education: Charting the course yourself'? Discourses of risk, cost and benefit through a perilous future. American in ethnically diverse, young working-class Accounting Association, Education Series 16, non-participants' constructions of higher Florida.

education. British Journal of Sociology of Education, 21(4), 555-574. http://dx.doi. 
org $/ 10.1080 / 713655373$

Arquero, J. L. (2000). Capacidades no técnicas en el perfil profesional en Contabilidad: las opiniones de docentes y profesionales. Revista Española de Financiación y Contabilidad, 29(103), 149-172.

Barnet, R. \& Di Napoli, R. (2008). Changing identities in Higher Education. Voicing Perspective. Routledge.

Bernabé, M. M., Sánchez, J. P. \& Vida, J. A. (2011). Nuevos criterios de valoración en las asignaturas de Contabilidad Financiera ¿Mejora de los resultados y de los conocimientos? Paper presented at the VIII Jornadas de Docencia en Contabilidad. Palma de Mallorca, Spain.

Biggs, J. (1999). Teaching for Quality Learning at University. Buckingham: SRHE and Open University Press.

Broad, M., McDonald, A. \& Matthews, M. (2000). Acceptability of accounting learning and teaching through the world wide web. Discussion Papers in Accounting and Management Science, Number 00-159, University of Southampton, Reino Unido.

Burnett, S. (2003). The future of accounting education: a regional perspective. Journal of Educationfor Business, 78(3), 129-134.http:// dx.doi.org/10.1080/08832320309599709
Cabrera, A. (2003). Evaluación de la formación. Madrid: Síntesis.

Camacho, M. M. (2012). El uso de mandos interactivos: una innovación docente para aumentar la motivación y mejorar el aprendizaje del alumnado universitario. Revista Teoría de la Educación: Educación y Cultura en la Sociedad de la Información. 13(1), 412-436.

Camilloni, A. (1998). La Evaluación De Los Aprendizajes En El Debate Didáctico

Contemporáneo. México: Paidos.

Cañibano, L. (2008). Higher education in "Business Administration" in Spain: Adapting to the European Area of Higher Education. Paper presented at the I Convegno Nazionale of SIDREA: La Ragioneria e l'economia aziendale: dinamiche evolutive e prospective di Cambiamento. Siena, Italy.

Carrasco, A., Donoso, J. A., Duarte, T., Hernández, J. J., López, R. \& Núñez, C. (2010). La utilización de metodologías activas de aprendizaje en la enseñanza de la contabilidad. Paper presented at the XIV Encuentro de la Asociación Española de Profesores Universitarios de Contabilidad. A Coruña, Spain.

Colen, M. T., Giné, N. \& Imbernón, F. (2006). La carpeta de aprendizaje del alumnado universitario. Barcelona: Octaedro.

Coll, C., Rochera-Villach, M. J., Mayordomo- 
Saíz, R. M. \& Naranjo, M. (2007). Evaluación continua y ayuda al aprendizaje. Análisis de una experiencia de innovación en educación superior con apoyo de las TIC. Electronic Journal of Research in Educational Phychology, 5, 783-804.

Council of Europe (2001). Common European Framework of Reference for Languages: Learning, Teaching and Assessment. Cambridge: Cambridge University Press. Retrieved August 21, 2010 from http://www. coe.int.

Cuadrado, I. \& Fernández, I. (2008). Nuevas competencias del profesor en el EEES: una experiencia de innovación docente. Revista Electrónica Teoría de la Educación. Educación y cultura de la sociedad de la información, $9(1)$.

Davidson, R. (2002). Relationship of study approach and exam performance. Journal of Accounting Education, 20(1), 29-44. http:// dx.doi.org/10.1016/S0748-5751(01)00025-2

Delgado, A. M. \& Olivier, R. (2006). La evaluación continua en un nuevo escenario docente. Revista de Universidad y Sociedad del Conocimiento, 3(1). Retrieved March 21, 2009 from http://www.uoc.edu/ojs/index. php/rusc/article/view/v3n1-delgado-oliver.

Delgado, A. M. \& Olivier, R. (2009). Interacción entre la evaluación continua y la autoevaluación formativa: la potenciación del aprendizaje autónomo. Red U: Revista de Docencia Universitaria, 4.

Demski, J. S. \& Zimmerman, J. L. (2000). On research versus teaching: a long perspective. Accounting Horizons, 14(3), 343-352. http:// dx.doi.org/10.2308/acch.2000.14.3.343

Díaz, F. (2002): Didáctica y curriculo: un enfoque constructivista. Universidad de Castilla La Mancha. Cuenca.

Dowling, C., Godfrey, J. M. \& Gyle, N. (2003). Do hybrid flexible delivery teaching methods improve accounting students' learning outcomes? Accounting Education: An International Journal, 12(4), 373-391. http:// dx.doi.org/10.1080/0963928032000154512

Drennan, L. G. \& Rohde, F. H. (2002). Determinants of performance in advanced undergraduate management accounting: An empirical investigation. Accounting and Finance, 42, 27-40. http://dx.doi. org/10.1111/1467-629X.00065

European Commission (2011). Informe del progreso sobre educación y formación. Bruselas: European Commission.

Farley, A. A. \& Ramsey, F. L. (1988). Student performance in first year tertiary accounting courses and its relationship to secondary accounting education. Accounting and Finance, 28(1), 29-44. http://dx.doi. org/10.1111/j.1467-629X.1988.tb00091.x 
Fernández-Barberís, G., Escribano-Ródenas, desarrollo profesional del profesorado. Hacia M. C. \& Bosch-Frigola, I. (2006). Evaluación una nueva cultura profesional. Biblioteca de continua en matemáticas en la universidad. Aula. Grao.

Minutes from the XIV Jornadas ASEPUMA

- II Encuentro Internacional de Profesores de Matemáticas (pp. 1-11). Badajoz: Ediciones de la Universidad de Extremadura.

Lei, J. (2010). Quantity versus quality: A new approach to examine the relationship between technology use and student outcomes. British Journal of Educational Technology, 41(3), Freeman, M. A. \& Capper, J. M. (1999). Exploiting the web for education: an 455-472. http://dx.doi.org/10.1111/j.1467anonymous asynchronous role simulation. Australian Journal of Educational Technology, 15(1), 95-116.

López, M. (2001). La evaluación del aprendizaje en el aula. Madrid: Edelvives.

Gandía, J. L. \& Montagud, M. D. (2011). López, M. V., Pérez, M. C. \& Rodríguez, L. Innovación docente y resultados del (2011). La incidencia del uso de actividades aprendizaje: un estudio empírico en la online en la tasa de éxito en la asignatura de enseñanza de la contabilidad de costes. Revista Contabilidad General. Paper presented at the Española de Financiación y Contabilidad, VIII Jornadas de Docencia en Contabilidad. 152, 677-698. http://dx.doi.org/10.1080/021 Palma de Mallorca, Spain.

02412.2011.10779716

López-Pastor, V. M. (Coord.) (2009). González, J. \& Wagenaar, R. (2003). Tuning Evaluación formativa y compartida en Educational Structures in Europe. Informe Educación Superior. Madrid: Narcea final. Proyecto Piloto-Fase 1. Bilbao: Ediciones.

Universidad de Deusto.

Mateos, A. \& Marín, M. M. (2009).

Healy, M. \& McCutcheon, M. (2010). Aplicación de las nuevas tecnologías en Teaching with Case Studies: An Empirical la docencia universitaria de Contabilidad. Investigation of Accounting Lecturers' Paper presented at the XV Congreso de Experiences. Accounting Education: An la Asociación Española de Contabilidad y International Journal, 19(6), 555-567, Administración de Empresas. Valladolid, http://dx.doi.org/10.1080/09639284.2010.50 Spain. 1577

Martí, C. P. (2012). Determinants of students' Imbernón, F. (1998). La formación y el performance in financial accounting. Paper 
presented at the 35th Annual Congress of Perera, L. \& Richardson, P. (2010). Students' European Accounting Association. Ljubljana, Use of Online Academic Resources within Slovenia. a Course Web Site and Its Relationship with Their Course Performance: An Martinello, M. \& Cook, G. (2000). Exploratory Study. Accounting Education: Interdisciplinary Inquiry in Teaching and An International Journal, 19(6), 587-600. Learning, 2nd ed., Pearson Education, NJ: http://dx.doi.org/10.1080/09639284.2010.52 Upper Saddle River. 9639

Mitchel, N., Cater, J. J. \& Varela, O. (2009). Pérez, P. J. \& Vila, L. E. (2012). Efectos de las Active versus passive teaching styles: an prácticas y métodos docentes sobre diferentes empirical study of student learning outcomes. medidas del output educativo: el caso de la Human Resource Development Quarterly, universidad española. Paper presented at 20(4), 397-418. http://dx.doi.org/10.1002/ the XXI Jornadas de la Asociación de la hrdq. 20025 Economía de la Educación. Oporto, Portugal.

Monereo, C. \& Pozo, J. L. (2003). La Pérez-Paredes, P. \& Rubio, F. (2005). Testing Universidad ante la nueva cultura educativa. and assessment. En D. Madrid, Mclaren, Enseñar y aprender para la autonomía. N. y Bueno, A. (eds.) TEFL in Secondary Barcelona: Síntesis.

Education. (pp. 605-639). Granada: Universidad de Granada.

Pascual, D., Camacho, M., Urquía, E. \& Muller, A. (2011). ¿Son los nuevos criterios de evaluación en el marco EEES adecuados para valorar el rendimiento académico de los alumnos? Experiencia en Contabilidad Financiera. Educade, 2, 67-83.

Plaza, F., Gómez, E., López, A., \& FernándezFuentes, A. (2010). Reflexiones en torno a una experiencia de Evaluación Continua en el EEES. Revista Docencia e Investigación, 20, 11-32.

Pasek, J., Kenski, K., Romer, D. \& Jamieson, K. H. (2006). America's youth and community engagement: How use of mass media is related to civic activity and political awareness among 14 to 22 years old. Communication Research, 33(3), 115-135. http://dx.doi. org $/ 10.1177 / 0093650206287073$

Pons, D. \& Mauleón, E. (2010). Análisis de la aplicación de la metodología docente derivada del Plan Bolonia en la asignatura Contabilidad Financiera I. Paper presented at the XIV Encuentro de la Asociación Española de Profesores Universitarios de Contabilidad. A Coruña, Spain. 
Porter, B. A. \& Carr, S. A. (1999). From Zabalza, M. A. (2003). Competencias docentes strategic plan to practical realities: Developing del profesorado universitario. Madrid: Narcea. and implementation a zero-based accounting Zafra, J. L., Román, I. \& Gómez, M. E. (2011). curriculum. Issues in Accounting Education, Influencia del uso de metodologías docentes 14(4), 565-588. http://dx.doi.org/10.2308/ combinadas en Análisis Contable sobre el iace.1999.14.4.565 rendimiento académico del alumno. Paper presented at the VIII Jornadas de Docencia

Rico Vercher, M. \& Rico Pérez, C. (2004). El en Contabilidad. Palma de Mallorca, Spain. Portfolio Discente. Alcoy: Marfil. 